\title{
Antimicrobial activity of isolated compounds and semisynthetic derivatives from Miconia ferruginata
}

\author{
Gracielle Oliveira Sabbag Cunhaa,b*, Ana Paula Terezanc, Andreia Pereira Matos ${ }^{\mathrm{d}}$, Marcela \\ Carmen de Melo Burgere, Paulo Cezar Vieiraf, João Batista Fernandesf , Maria Fátima das \\ Graças Fernandes da Silvaf, Antônio Carlos Severo Menezesa \\ a Programa de Pós-Graduação em Química, Universidade Estadual de Goiás, Anápolis, 75132-903, Goiás, Brazil. \\ *graciellesabbag@gmail.com \\ b Instituto Federal de Goiás, Anápolis, 75131-457, Goiás, Brazil. \\ c Universidade Federal de Goiás, Goiânia, 74690-900, Goiás, Brazil. \\ d Centro de Ciências da Natureza, Universidade Federal de São Carlos, Buri, 18245-970, São Paulo, Brazil. \\ e Instituto Federal Goiano, Ceres, 76300-000, Goiás, Brazil. \\ f Programa de Pós-Graduação em Química, Universidade Federal de São Carlos, São Carlos, 13565-905, São Paulo, Brazil,
}

Recebido: September 2, 2019 / Aceito: October 22, 2019 / Publicado online: January 20, 2020

\begin{abstract}
This study evaluated the antimicrobial activity of isolated compounds and semisynthetic derivatives from Miconia ferruginata (Melastomataceae) against five microorganisms: Staphylococcus aureus (ATCC 25923), Escherichia coli (ATCC 25922), Bacillus subtilis (ATCC 6623), Pseudomonas aeruginosa (ATCC 15442), and Candida albicans (ATCC 10231). The isomeric mixture of ursolic and oleanolic acids was active against $S$. aureus $\left(\mathrm{MIC}=250 \mu \mathrm{g} \mathrm{mL}^{-1}\right.$ ) and against $E$. coli, B. subtilis, and $P$. aeruginosa $\left(\mathrm{MIC}=500 \mu \mathrm{g} \mathrm{mL} \mathrm{m}^{-1}\right)$. The flavone 5,6,7-trihydroxy-4'-methoxyflavone and the methyl esters, semisynthetic derivatives of a mixture of ursolic and oleanolic acids, showed no activity against the tested microorganisms. These results suggest that the carboxyl group present in the triterpenes may contribute to antimicrobial activity.
\end{abstract}

Keywords: Melastomataceae, Oleanolic acid, , triterpenes, ursolic acid.

\section{Atividade antimicrobiana de compostos isolados e derivados semissintéticos de Miconia ferruginata}

\begin{abstract}
Resumo
Este estudo descreve a avaliação da atividade antimicrobiana de compostos isolados e derivados semissintéticos de Miconia ferruginata (Melastomataceae) contra cinco microorganismos: Staphylococcus aureus (ATCC 25923), Escherichia coli (ATCC 25922), Bacillus subtilis (ATCC 6623), Pseudomonas aeruginosa (ATCC 15442) and Candida albicans (ATCC 10231). A mistura isomérica dos ácidos ursólico e oleanólico foi ativa contra $S$. aureus $\left(\mathrm{CIM}=250 \mu \mathrm{g} \mathrm{mL}^{-1}\right)$ e contra E. coli, B. subtilis e $P$. aeruginosa $\left(\mathrm{CIM}=500 \mu \mathrm{g} \mathrm{mL} \mathrm{m}^{-1}\right)$. A flavona 5,6,7-trihidroxi-4'-metóxiflavona e os ésteres metílicos, derivados semissintéticos da mistura dos ácidos ursólico e oleanólico, não apresentaram atividade contra os microrganismos testados. Estes resultados sugerem que o grupo carboxila presente nos triterpenos podem contribuir para a atividade antimicrobiana.
\end{abstract}

Palavras-chave: Melastomataceae, Ácido oleanólico, triterpenos, ácido ursólico.

\section{Introduction}

Infectious diseases are a significant cause of morbidity and mortality worldwide. On account that resistant microorganisms can be selected by antibiotics, attention has been paid to discover new and efficient "smart" antimicrobial drugs to counter the spread of resistance to current antibiotics (Heinemann, 2001). There is also growing interest in studying alternative antimicrobial agents, e.g., antibacterial peptides produced by microorganisms (Liu, Ding, Shen and Zhu, 2019) and plant-derived compounds (Barbieri et al., 2017).
Antimicrobials of plant origin are effective in the treatment of infectious diseases and can alleviate many of the side effects often associated with synthetic antimicrobials (Savant, Venkatesh, Mannasaheb and Joshi, 2014). There are several major groups of antimicrobial compounds of plant origin: phenolics and polyphenols (including simple phenols and phenolic acids, quinines, flavones, flavonoids and flavonols, tannins and coumarins), terpenoids, essential oils, alkaloids, lectins, and polypeptides (Wolska, Grudniak, Fiecek, Kraczkiewicz-Dowjat and Kurek, 2010). 
Ethnobotanical studies reported varied popular uses of species of the genus Miconia (Boscolo and Valle, 2008), although several plants of this genus are still poorly studied. In this context, this is the first study reporting the antimicrobial activity of isolated compounds from M. ferruginata.

Belonging to the family Melastomataceae (Renner, 1993), Miconia is a genus of approximately 1050 species (Goldenberg, Penneys, Almeda, Judd and Michelangeli, 2008), occurring in tropical America. Biological activities reported for Miconia species mainly include antimicrobial (Cunha et al., 2010), analgesic and anti-inflammatory (Vasconcelos et al., 2006), antimutagenic (Gontijo et al., 2019), antitumoral (Cunha et al., 2008), trypanosomicidal (Cunha et al., 2006), leishmanicidal (Peixoto et al., 2011), and insecticidal (Cunha et al., 2017). The current study was carried out to determine the in vitro antimicrobial activity of isolated compounds and semisynthetic derivatives from Miconia ferruginata DC.

\section{Materials and Methods}

\section{Plant material}

Miconia ferruginata leaves were collected at the Cerrado of the Universidade Estadual de Goiás, Anápolis city, Goiás State, Brazil. Voucher specimens (5794) have been deposited in the Herbarium of the same University.

\section{Compounds extraction and isolation}

In previous work, Cunha et al. (2017) isolated a mixture of ursolic (1) and oleanolic (2) acids and the flavone 5,6,7trihydroxy-4'-methoxyflavone (3) from the ethanolic extract of $M$. ferruginata leaves. The mixture of ursolic and oleanolic acid was converted to their methyl esters, methyl ursolate and methyl oleanolate, (1a) and (2a), respectively, by the action of diazomethane (Leonard, Lygo and Procter, 1995), aiming to verify the structure-activity relationship of the molecules. The purity of compounds was determined by TLC and analyzed from their ${ }^{1} \mathrm{H}$ NMR spectrum. No contamination or byproducts were found.

\section{Antimicrobial assay}

Antimicrobial assays were performed using the broth microdilution technique proposed by the Clinical and Laboratory Standards Institute (CLSI) protocols M7-A6 and M27-A2 (adapted) for determining the MIC (lowest concentration able to inhibit the growth of microorganisms). All MIC determinations were performed in triplicate in 96-well microplates. The following microorganisms belonging to the American Type Culture Collection were used: Staphylococcus aureus (ATCC 25923), Escherichia coli (ATCC 25922), Bacillus subtilis (ATCC 6623), Pseudomonas aeruginosa (ATCC 15442), and Candida albicans (ATCC 10231). The stock solutions of tested samples (mixture of 1 and 2, mixture of 1a and 2a, 3) were prepared in Eppendorf vials solubilizing $1 \mathrm{mg}$ of sample in $40 \mu \mathrm{L}$ of DMSO. These solutions were diluted in $960 \mu \mathrm{L}$ of Mueller-Hinton broth for bacteria or Sabouraud broth for testing with yeast. From this solution the final concentrations ranged from 7.81 to $500 \mu \mathrm{g} \mathrm{mL}^{-1}$. The inocula were standardized based on a scale of 0.5 McFarland turbidity standard $\left(10^{8} \mathrm{CFU} / \mathrm{mL}\right)$ and diluted at $1: 10$ ratio to the broth microdilution procedure. After micropipetting, microplates were capped and incubated at $37{ }^{\circ} \mathrm{C}$ for $18-24 \mathrm{~h}$ without agitation. After the incubation period, results were visualized and the wells that showed no apparent growth were selected to determine the antimicrobial activity of samples. This determination was performed using subcultures in Petri dishes with Mueller-Hinton agar for growing bacteria and Sabouraud agar for growing fungus. The Petri dishes were incubated at $37{ }^{\circ} \mathrm{C}$ for $48 \mathrm{~h}$, being verified the presence/absence of microbial colonies. After preparation of subcultures, $15 \mu \mathrm{L}$ of $0.01 \%$ resazurin in sterile aqueous solution were added to each well of the microplates. Reading was performed after $4 \mathrm{~h}$ of reincubation. Thus, in each extract, it was possible to determine the lowest concentration able to inhibit the growth of microorganisms through indicators in diluted solution. All tests were performed with negative control (DMSO), positive control (vancomycin chlorhydrate, tetracycline chlorhydrate, and nystatin), microorganism growth control, and sample precipitation control, avoiding possible falsenegative or false-positive results.

\section{Results and Discusion}

The chemical study of the ethanol extract of $M$. ferruginata leaves resulted in the identification of the triterpenes ursolic acid (1) and oleanolic acid (2) (mixture) and the flavone 5,6,7-trihydroxy-4'-methoxyflavone (3), in addition to the semisynthetic derivatives methyl ursolate (1a) and methyl oleanolate (2a) (mixture) (Figure 1).
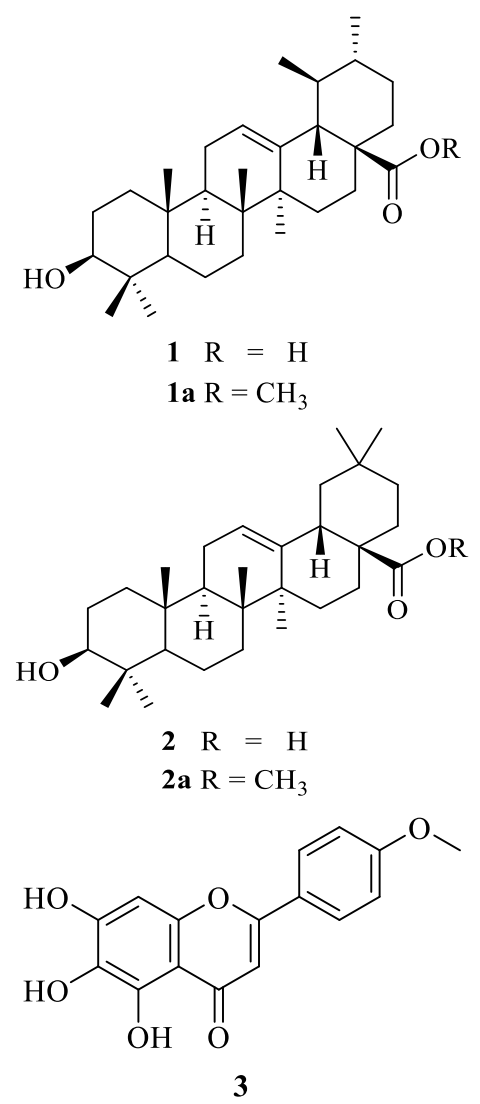

Figure 1. Chemical structures of isolated compounds and semisynthetic derivatives from M. ferruginata. 
The mixture of ursolic and oleanolic acids showed inhibition against $B$. subtillis, $E$. coli, $P$. aeruginosa $(\mathrm{MIC}=$ $500 \mu \mathrm{g} \mathrm{mL}^{-1}$ ), and $S$. aureus $\left(\mathrm{MIC}=250 \mu \mathrm{g} \mathrm{mL}^{-1}\right.$ ). There was no activity against $C$. albicans in the tested concentration (Table 1).
This antimicrobial activity is not so intense compared with antimicrobial drugs that are used clinically. However, it has been reported that ursolic and oleanolic acids are not so toxic (Liu, 1995) and possess antimicrobial activity against some resistant bacteria (Jesus et al., 2015).

Table 1. Minimum inhibitory concentration (MIC in $\mu \mathrm{g} \mathrm{mL}^{-1}$ ) values obtained for isolated compounds and derivatives from M. ferruginata.

\begin{tabular}{cccccc}
\hline Sample & B. subtilis & E. coli & S. aureus & P. aeruginosa & C. albicans \\
\hline $1+2$ & 500 & 500 & 250 & 500 & $>500$ \\
$1 \mathrm{a}+2 \mathrm{a}$ & $>500$ & $>500$ & $>500$ & $>500$ & $>500$ \\
3 & $>500$ & $>500$ & $>500$ & $>500$ & $>500$ \\
Positive Control & $0.048^{*}$ & $3.125^{* *}$ & $0.750^{* *}$ & $1.562^{* *}$ & $6.250^{* * *}$ \\
\hline
\end{tabular}

${ }^{*}$ Vancomycin chlorhydrate, ${ }^{* *}$ Tetracycline chlorhydrate, ${ }^{* * *}$ Nystatin.

Methyl esters derivatives were also tested for their in vitro antimicrobial activity to evaluate structure-activity relationships. Introduction of the methyl group into the C-28 of the triterpenes led to disappearance of the antimicrobial activity. For the methyl esters $1 \mathrm{a}$ and $2 \mathrm{a}$ in mixture, there was neither antibacterial activity against the strains tested, nor antifungal activity against $C$. albicans. It is suggested that the carboxyl group may contribute to inhibitory activity. The flavone 5,6,7-trihydroxy-4'-methoxyflavone (3) did not showed antimicrobial activity.

Previous phytochemical investigations of Miconia species resulted in isolation of triterpenes (Cunha et al., 2017), flavonoids (Lima et al., 2018), tannins (Rodrigues et al., 2011), and quinone compounds (Viegas et al., 2019). The antimicrobial activity of extracts from Miconia species has been reported in the literature to be active against several microorganisms (Gontijo et al., 2019). Furthermore, the antimicrobial properties of several triterpene acids have also been studied (Cunha et al., 2010).

Triterpene acids isolated from Miconia species along with a mixture of those triterpenes, as well as semisynthetic derivatives, were evaluated by Cunha et al. (2007) against Streptococcus mutans, Streptococcus mitis, Streptococcus sanguinis, Streptococcus salivarius, Streptococcus sobrinus, and Enterococcus faecalis, which are potentially responsible for the formation of dental caries in humans. The triterpenes ursolic, oleanolic, gypsogenic, and sumaresinolic acids, along with a mixture of ursolic and oleanolic acids, as well as ursolic acid derivatives, displayed activity against all the tested bacteria, showing that they are promising antiplaque and anticaries agents (Cunha et al., 2007).

In addition to antimicrobial activity, triterpenes isolated from Miconia species have been evaluated for other biological activities. Ursolic and oleanolic acids isolated from the crude methylene chloride extract of Miconia albicans aerial parts exhibit anti-inflammatory and analgesic activities (Vasconcelos et al., 2006). In a study of the trypanocidal activity of triterpene acids isolated from Miconia sellowiana and Miconia ligustroides species, Cunha et al. (2006) showed that ursolic and oleanolic acids were the most active against the trypomastigote blood forms of Trypanosoma cruzi. Peixoto et al. (2011) evaluated the antileishmanial activity of the crude hydroalcoholic extract of Miconia langsdorffii. The fractionation of this extract led to identification of the triterpenes ursolic and oleanolic acids as the major compounds in the fraction that displayed the highest activity. These compounds gave $\mathrm{IC}_{50}$ values of $360.3 \mu \mathrm{M}$ and 439.5 $\mu \mathrm{M}$, respectively. In addition, a mixture of the triterpenes displayed increased antileishmanial activity, with an $\mathrm{IC}_{50}$ of 199.6 $\mu \mathrm{M}$ (Peixoto et al., 2011).

Studies to identify the cellular targets and molecular mechanisms of ursolic and oleanolic acids action were initiated a few years ago and it has already been demonstrated that both acids influence bacterial gene expression, the formation and maintenance of biofilms, cell autolysis, and peptidoglycan turnover. Before these compounds can be used clinically as antimicrobial agents, further extensive studies are required to determine their cytotoxicity and the optimum mode of their application (Wolska et al., 2010).

\section{Conclusion}

The present study shows that the isomeric mixture of ursolic and oleanolic acids isolated from $M$. ferruginata leaves was active against $S$. aureus, E. coli, B. subtilis, and $P$. aeruginosa. However, for the methyl esters derivatives methyl oleanolate and methyl ursolate, and for the flavone 5,6,7-trihydroxy-4'-methoxyflavone, there was neither antibacterial activity against the strains tested, nor antifungal activity against $C$. albicans. It is suggested that the carboxyl group present in the triterpenes may contribute to antimicrobial activity.

\section{References}

Barbieri, R., Coppo, E., Marchese, A., Daglia, M., Sobarzo-Sánchez, E., Nabavi, S.F., \& Nabavi, S. M. (2017). Phytochemicals for human disease: An update on plant-derived compounds antibacterial activity. Microbiological Research, (196), 44-68. doi:10.1016/j.micres.2016.12.003

Boscolo, O.H. \& Valle, L.S. (2008). Plantas de uso medicinal em Quissamã, Rio de Janeiro, Brasil. Editora Iheringia: Série Botânica. 63(2), 263277.

Clinical and Laboratory Standards Institute. (2003). Methods for Dilution Antimicrobial Susceptibility Tests for Bacteria That Grow Aerobically, Approved Standard - M7-A6, 6th ed., NCCLS/CLSI: Wayne, vol. 23.

Cunha, L.C.S., Silva, M.L.A., Furtado, N.A.J.C., Vinhólis, A.H.C., Martins, C.H.G., da Silva Filho, A.A., \& Cunha, W.R. (2007). Antibacterial activity of triterpene acids and semi-synthetic derivatives against oral pathogens. Zeitschrift für Naturforschung C, 62(9-10), 668-672. doi:10.1515/znc-2007-9-1007 
Cunha, G.O.S., Matos, A.P., Bernardo, A.R., Menezes, A.C.S., Burger, M.C.M., Vieira, P.C., Forim, M.R., Fernandes, J.B., \& Silva, M.F.G.F. (2017). Constituintes químicos e atividade inseticida de Miconia ferruginata. Química Nova, (40), 1158-1163. doi:10.21577/01004042.20170126

Cunha, W.R., Crevelin, E.J., Arantes, G.M., Crotti, A.E.M., Andrade e Silva, M. L., Furtado, N.A.J.C., Albuquerque, S., \& Ferreira, D.S. (2006). A study of the trypanocidal activity of triterpene acids isolated from Miconia species. Phytotherapy Research, 20(6), 474-478. doi:10.1002/ptr.1881

Cunha, W.R., Matos, G.X., Souza, M.G.M., Tozatti, M.G., Andrade e Silva, M.L., Martins, C.H.G., Silva, R., \& Filho, A.A.S. (2010). Evaluation of the antibacterial activity of the methylene chloride extract of Miconia ligustroides, isolated triterpene acids, and ursolic acid derivatives. $\begin{array}{lll}\text { Pharmaceutical } & \text { Biology, } & \text { 48(2), }\end{array}$ doi:10.3109/13880200903062648

Cunha, W.R., Silva, M.L.A., Santos, F.M., Montenegro, I.M., Oliveira, A.R.A., Tavares, H.R., Santos, H.S.L., \& Bizário, J.C.S. (2008). In vitro Inhibition of tumor cell growth by Miconia fallax. Pharmaceutical Biology, 46(4), 292-294. doi:10.1080/13880200701741245

Goldenberg, R., Penneys, D.S., Almeda, F., Judd, W.S., \& Michelangeli, F.A. (2008). Phylogeny of Miconia (Melastomataceae): patterns of stamen diversification in a megadiverse neotropical genus. International Journal of Plant Sciences, 169(7), 963-979. doi:10.1086/589697

Gontijo, D.C., Gontijo, P.C., Brandão, G.C., Diaz, M.A.N., Oliveira, A.B., Fietto, L.G., \& Leite, J.P.V. (2019). Antioxidant study indicative of antibacterial and antimutagenic activities of an ellagitannin-rich aqueous extract from the leaves of Miconia latecrenata. Journal of Ethnopharmacology, (236), 114-123. doi:10.1016/j.jep.2019.03.007

Heinemann, J.A. (2001). Can smart bullets penetrate magic bullet-proof vest? Drug Discovery Today, 6(17), 875-878. doi:10.1016/S13596446(01)01857-8

Jesus, J.A., Lago, J.H.G., Laurenti, M.D., Yamamoto, E.S., \& Passero, L.F.D. (2015). Antimicrobial activity of oleanolic and ursolic acids: An update. Evidence-Based Complementary and Alternative Medicine, (2015), 1-14. doi:10.1155/2015/620472

Leonard, J., Lygo, B., \& Procter, G. (1995). Advanced Practical Organic Chemistry. 2a ed. Oxford: Chapman \& Hall.

Lima, R.C.L., Kongstad, K.T., Kato, L., das Silva, M.J., Franzyk, H., \& Staerk, D. (2018). High-Resolution PTP1B Inhibition Profiling Combined with HPLC-HRMS-SPE-NMR for Identification of PTP1B Inhibitors from $\begin{array}{llll}\text { Miconia albicans. } & \text { Molecules, } & \text { 23(7), } & 1755 .\end{array}$ doi:10.3390/molecules23071755

Liu J. (1995). Pharmacology of oleanolic acid and ursolic acid. Journal of Ethnopharmacology, 49(2), 57-68. doi:10.1016/0378-8741(95)90032-2

Liu, Y., Ding, S., Shenab, \& J., Zhu, K. (2019). Nonribosomal antibacterial peptides that target multidrug-resistant bacteria. Natural Product Reports, 36(4), 573-592. doi:10.1039/c8np00031j

Peixoto, J.A., Andrade e Silva, M.L., Crotti, A.E.M., Veneziani, R.C.S., Gimenez, V.M.M., Januário, A.H., Groppo, M., Magalhães, L.G., dos Santos, F.F., Albuquerque, S., da Silva Filho, A.A., \& Cunha, W.R. (2011). Antileishmanial activity of the hydroalcoholic extract of Miconia langsdorffii, isolated compounds, and semi-synthetic derivatives. Molecules, 16(2), 1825-1833. doi:10.3390/molecules16021825

Renner, S.S. (1993). Phylogeny and classification of the Melastomataceae and Memecylaceae. Nordic Journal of Botany, 13 (5), 519-540. doi:10.1111/j.1756-1051.1993.tb00096.x

Rodrigues, J., Rinaldo, D., da Silva, M.A., dos Santos, L.C., \& Vilegas, W. (2011). Secondary Metabolites of Miconia rubiginosa. Journal of Medicinal Food, 14(7-8), 834-839. doi:10.1089/jmf.2010.0157

Savant, C., Venkatesh, Mannasaheb, B.A., \& Joshi, H. (2014). Importance of antimicrobial agents from plants in present scenario: a review. International Journal of pharmacognosy, 1(8), 472-484. doi:10.13040/IJPSR.0975-8232.IJP.1(8).472-84

Vasconcelos, M.A.L, Royo, V.A., Ferreira, D.S., Crotti, A.E.M., Andrade e Silva, M.L., Carvalho, J.C., Bastos, J.K., \& Cunha, W.R. (2006). In vivo analgesic and anti-inflammatory activities of ursolic acid and oleanoic acid from Miconia albicans (Melastomataceae). Zeitschrift für Naturforschung C, 61(7-8), 477-482. doi:10.1515/znc-2006-7-803

Viegas, F.P.D., Espuri, P.F., Oliver, J.C., Silva, N.C., Dias, A.L.T., Marques, M.J., \& Soares, M.G. (2019). Leishmanicidal and antimicrobial activity of primin and primin-containing extracts from Miconia willdenowii.
Fitoterapia, (138), 1-5. doi:10.1016/j.fitote.2019.104297

Wolska, K.I., Grudniak, A.M., Fiecek, B., Kraczkiewicz-Dowjat, A., \& Kurek, A. (2010). Antibacterial activity of oleanolic and ursolic acids and their derivatives. Central European Journal of Biology, 5(5), 543553. doi:10.2478/s11535-010-0045-x

\section{License: Creative Commons CC BY 4.0}

This article was published with open access for distribution under the terms of the Creative Commons Attribution License, which allows unrestricted use, distribution, and reproduction in any medium, provided the original work is properly cited. 